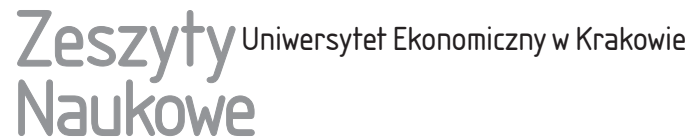

\section{Praktyczne aspekty ujednolicenia obowiązków sprawozdawczych organizacji pożytku publicznego}

\section{Streszczenie}

Nowelizacja ustawy o rachunkowości z dnia 15 grudnia 2016 r. wprowadziła nowe ujednolicone wzory sprawozdań finansowych dla organizacji pożytku publicznego, które mają zastosowanie dla sprawozdań sporządzanych za okresy rozpoczynające się po 1 stycznia 2017 r. Artykuł w syntetyczny sposób przedstawia praktyczne aspekty wprowadzenia nowych regulacji. W opinii autora nowy wzór sprawozdania lepiej wpisuje się w specyfikę działalności organizacji trzeciego sektora, eliminując jednocześnie problemy związane z koniecznością dostosowywania dotychczasowych wzorów sprawozdań do wymogów ujawniania przychodów i kosztów działalności nieodpłatnej, odpłatnej i gospodarczej. Zaprezentowane zostały także wyniki badań przeprowadzonych na próbie organizacji prowadzących działalność w województwie małopolskim, ukazujące skalę problemu właściwego doboru wzorów sprawozdań finansowych.

Słowa kluczowe: organizacje pożytku publicznego, fundacje, stowarzyszenia, ujednolicenie sprawozdań finansowych.

Klasyfikacja JEL: M41.

\section{Wprowadzenie}

Obowiązki sprawozdawcze organizacji pożytku publicznego (OPP) podlegają ciągłym zmianom. W ostatnich latach kilkukrotnie zmieniano wzory sprawozdań

Paweł Zieniuk, Uniwersytet Ekonomiczny w Krakowie, Wydział Finansów i Prawa, Katedra Rachunkowości Finansowej, ul. Rakowicka 27, 31-510 Kraków, e-mail: pawel.zieniuk@uek.krakow.pl 
finansowych, zwiększano zakres informacji ujawnianych w sprawozdaniach merytorycznych z działalności pożytku publicznego, wprowadzono także nowe regulacje związane z terminami i formą podawania sprawozdań do publicznej wiadomości. Głównym celem artykułu jest ocena wprowadzanych zmian w kontekście specyfiki działalności społecznie użytecznej, prowadzonej w sferze zadań publicznych.

Na podstawie analizy aktów prawnych przedstawiono najnowsze zmiany obowiązków sprawozdawczych organizacji pożytku publicznego przy uwzględnieniu problemów związanych z ich praktyczną realizacją. Prezentowane rozważania wynikają także z przeprowadzonych własnych badań empirycznych na próbie 100 organizacji publikujących sprawozdania finansowe i merytoryczne na stronach Ministerstwa Rodziny, Pracy i Polityki Społecznej (http://sprawozdaniaopp.mpips. gov.pl, data dostępu: 16.08.2017) oraz 72 fundacji i stowarzyszeń prowadzących działalność pożytku publicznego w województwie małopolskim, nieposiadających statusu OPP i niepodlegających obowiązkowi publikacji sprawozdań w bazie ministerialnej.

Organizacje objęte są obowiązkiem prowadzenia przejrzystej i rzetelnej rachunkowości, przede wszystkim dla zapewnienia poprawności rozliczenia środków pozyskiwanych z różnych źródeł i zaspokojenia potrzeb informacyjnych szerokiej grupy odbiorców sprawozdań, wśród których znajdują się także potencjalni darczyńcy, fundatorzy oraz podmioty przyznające dotacje i granty. Społeczne cele działalności organizacji są natomiast jedną z głównych przyczyn powszechnej akceptacji wprowadzania uproszczeń w obowiązkach rachunkowych i sprawozdawczych organizacji. Obecnie obowiązujący model sprawozdawczości organizacji jest więc swoistym kompromisem pomiędzy dążeniem do zwiększania przydatności ujawnianych w sprawozdaniu informacji a obserwowaną tendencją wprowadzania uproszczeń ograniczających koszty obsługi księgowej, mogące stanowić istotną barierę rozwoju jednostek trzeciego sektora.

\section{Obowiązki sprawozdawcze organizacji pożytku publicznego i ich praktyczna realizacja}

Na sposób prowadzenia rachunkowości oraz zakres wymaganych obowiązków sprawozdawczych organizacji pożytku publicznego ma wpływ wiele czynników, takich jak przedmiot działalności organizacji, forma organizacyjnoprawna, w jakiej działa dana jednostka, posiadanie przez organizację statusu organizacji pożytku publicznego oraz to, czy zdecydowała się ona na prowadzenie działalności gospodarczej. Obowiązujące regulacje dają organizacjom możliwość skorzystania $\mathrm{z}$ uproszczeń w realizacji obowiązków rachunkowych, co również uzależnione jest od spełniania przez nie określonych warunków. 
Organizacje nieprowadzące działalności gospodarczej za lata sprawozdawcze 2001-2013 sporządzały sprawozdania finansowe na wzorach wynikających z rozporządzenia Ministra Finansów z dnia 15 listopada 2001 r. Sprawozdanie składało się z bilansu, rachunku wyników i informacji dodatkowej. Wzory sprawozdań w dużym stopniu uwzględniały specyfikę działalności jednostek non-profit. Stosowanie określenia „rachunek wyników” zamiast „rachunek zysków i strat” oraz zastąpienie pojęć zysku i straty odpowiednio nadwyżką przychodów i nadwyżką kosztów podkreślało, że osiąganie zysku nie jest głównym celem działalności tych podmiotów. Wzór rachunku wyników pozwalał też na odczytanie wprost osiągniętego wyniku z działalności statutowej, który w przypadku jednostek non-profit posiada dużą wartość informacyjną.

Nowelizacja ustawy o rachunkowości (Ustawa z dnia 11 lipca 2014 r....) wprowadziła dla organizacji nieprowadzących działalności gospodarczej nowe wzory sprawozdań, zgodne z załącznikiem nr 4 do ustawy. Tym samym organizacje te zostały uznane za jednostki mikro, niezależnie od wysokości sumy bilansowej, osiąganych przychodów i liczby pracowników. Wszystkie organizacje nieprowadzące działalności gospodarczej, niezależnie od skali ich działalności, mogły jako jednostki mikro sporządzać sprawozdania w tej wersji za lata sprawozdawcze 2014-2016.

Omawiane sprawozdania składały się z bilansu, rachunku zysków i strat oraz informacji dodatkowej. Zrównanie obowiązków sprawozdawczych organizacji z przedsiębiorstwami uznanymi za jednostki mikro sprawiło, że praktyczna realizacja obowiązków sprawozdawczych dla organizacji została utrudniona. Sporządzanie rachunku zysków i strat w wersji porównawczej bez uwzględnienia specyfiki działalności pożytku publicznego wiązało się z potrzebą modyfikacji wzoru sprawozdania pozwalającego na prezentację przychodów i kosztów działalności statutowej, co jednostki realizowały z różnym skutkiem. O niezrozumieniu istoty działalności non-profit świadczyła też zmiana nazwy zestawienia przychodów i kosztów z rachunku wyników na rachunek zysków i strat. Warto też podkreślić, że wprowadzone w 2014 r. zmiany nie spotkały się z akceptacją środowiska organizacji pozarządowych (Odpowiedź Ogólnopolskiej Federacji Organizacji Pozarzqdowych... 2014, s. 1-2). Według przedstawionego stanowiska nie korespondowały one ze specyfiką sektora pozarządowego, a pożądane było odrębne uregulowanie problematyki sprawozdawczości jednostek prowadzących działalność społeczną.

O lepszym odbiorze wcześniejszych wzorów sprawozdań oraz praktycznym problemie ze sporządzaniem przez organizacje sprawozdań w wersji dla jednostek mikro świadczy liczba jednostek, które mimo ustawowego obowiązku nadal sporządzała sprawozdania na wzorach wynikających z rozporządzenia Ministra Finansów z dnia 15 listopada 2001 r. Na rys. 1 przedstawiono odsetek organizacji 
sporządzających za lata sprawozdawcze 2014-2016 sprawozdania według wzorów z rzeczonego rozporządzenia oraz według obowiązujących w tych latach wzorów dla jednostek mikro. Dane dotyczą próby 72 wybranych fundacji i stowarzyszeń prowadzących działalność w województwie małopolskim.

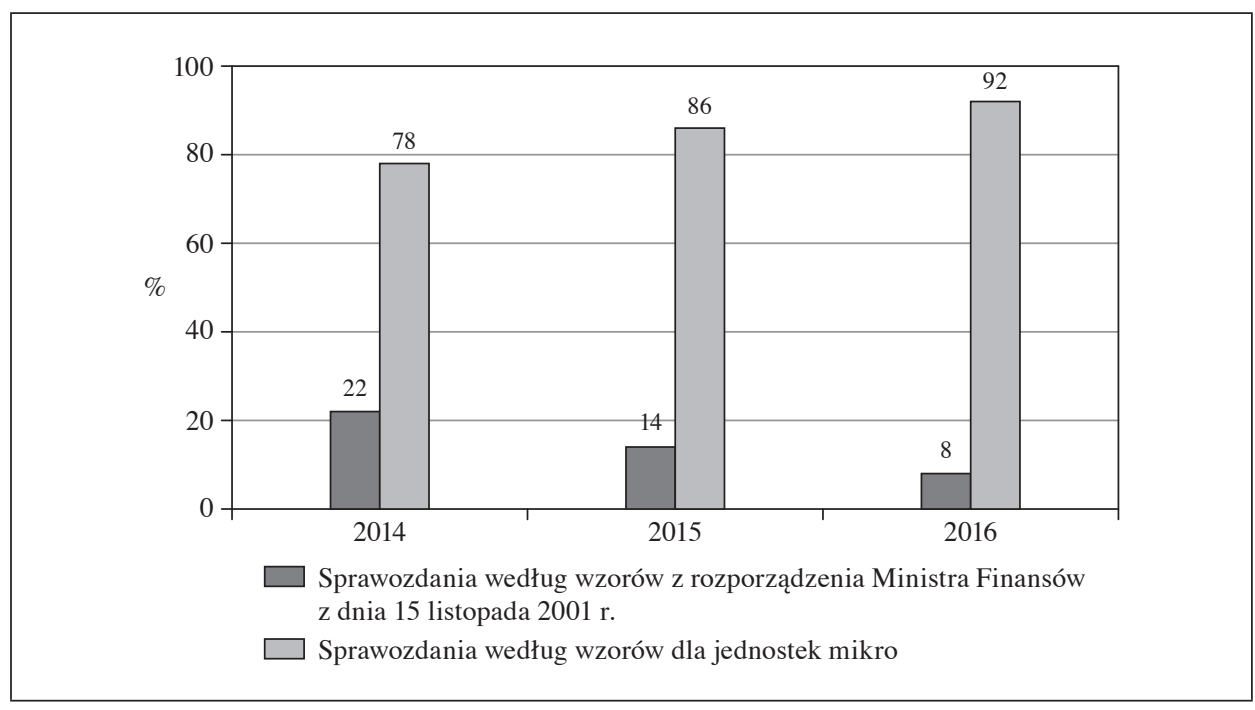

Rys. 1. Struktura organizacji ze względu na zastosowane wzory sprawozdań finansowych w latach 2014-2016

Źródło: opracowanie własne.

Należy zaznaczyć, że niewłaściwy dobór wersji sprawozdania może dotyczyć tylko organizacji niepublikujących sprawozdań w bazie Ministerstwa Rodziny, Pracy i Polityki Społecznej. W przypadku organizacji nieprowadzących działalności gospodarczej i posiadających status OPP (próba 100 jednostek), a tym samym zobligowanych do publikacji sprawozdań na stronach ministerstwa, problem ten nie występuje. Wynika to jednak ze specyfiki mechanizmu publikacji, który nie pozwala na sporządzenie sprawozdania na nieobowiązującym aktualnie wzorze.

Badania sektora organizacji pozarządowych przeprowadzone przez Stowarzyszenie Klon/Jawor wykazały, że dla 34\% organizacji obowiązek prowadzenia księgowości stanowi odczuwalny problem, $10 \%$ organizacji nie prowadzi żadnej księgowości, a w co trzeciej z nich księgowość jest prowadzona przez osoby, które nie posiadają formalnych uprawnień (Podstawowe fakty o organizacjach pozarzqdowych... 2013 s. 177-182). Odsetek organizacji realizujących obowiązki księgowe i sprawozdawcze systematycznie rośnie, co zilustrowano na rys. 2. 


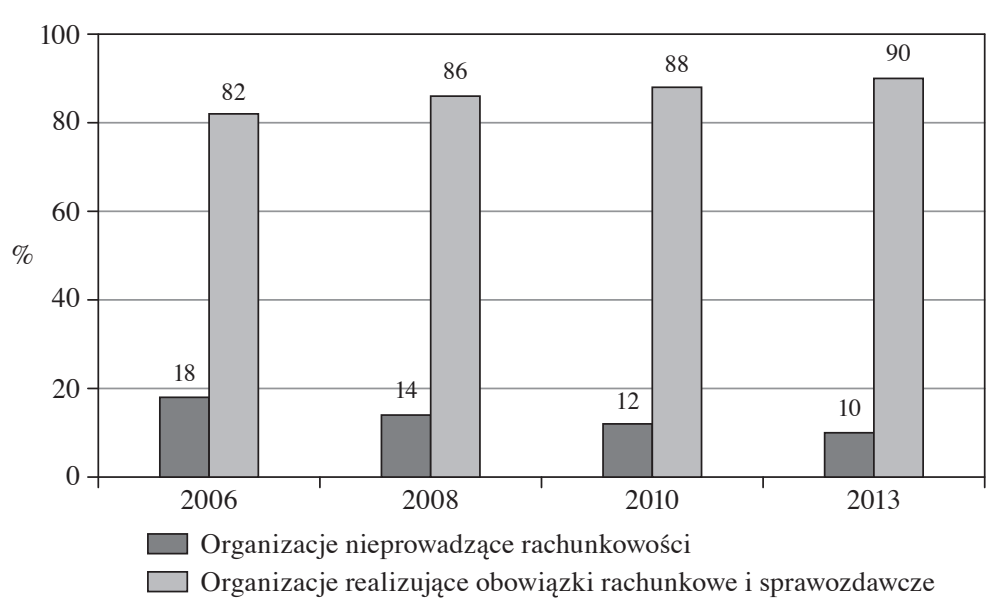

Rys. 2. Struktura organizacji ze względu na realizację obowiązków rachunkowych i sprawozdawczych

Źródło: opracowanie własne na podstawie (Podstawowe fakty o organizacjach pozarzqdowych... 2013, s. 182).

Skala niewłaściwego doboru sprawozdań finansowych pozwala przypuszczać, że wprowadzenie kolejnych zmian od roku sprawozdawczego 2017 może wywołać w organizacjach dalsze problemy, co może prowadzić do sporządzania sprawozdań o różnej wartości informacyjnej.

\section{Ujednolicenie wzorów sprawozdań finansowych organizacji pożytku publicznego}

Nowelizacja ustawy o rachunkowości (Ustawa z dnia 15 grudnia 2016 r....) wprowadziła ujednolicone wzory sprawozdań finansowych dla organizacji pożytku publicznego, wynikające $\mathrm{z}$ nowego załącznika nr 6 do ustawy, które po raz pierwszy będą miały zastosowanie do sprawozdań sporządzanych za rok obrotowy rozpoczynający się od dnia 1 stycznia 2017 r. Nowe wzory bilansu, rachunku zysków i strat oraz informacji dodatkowej w opinii autora lepiej wpisują się w specyfikę organizacji pożytku publicznego.

Układ prezentacyjny rachunku zysków i strat pozwala na wyodrębnienie wyniku finansowego osiąganego z działalności statutowej i działalności gospodarczej, co nie było możliwe do odczytania wprost $\mathrm{z}$ dotychczasowych wersji sprawozdań. Wyeliminowana została także konieczność modyfikacji obowiązujących 
wzorów, związana z koniecznością wyodrębniania przychodów i kosztów działalności nieodpłatnej i odpłatnej. Odpowiednie pozycje sprawozdawcze znalazły się w nowo obowiązującym wzorze rachunku zysków i strat. Za niedopatrzenie należy uznać odstąpienie od posługiwania się określeniami „nadwyżka przychodów” lub „nadwyżka kosztów” w odniesieniu do wyniku finansowego jednostek nieprowadzących działalności gospodarczej (non-profit). Porównanie zakresu informacyjnego dotychczasowych wersji rachunku wyników z rozporządzenia Ministra Finansów z dnia 15 listopada 2001 r. oraz rachunku zysków i strat z nowelizacji ustawy o rachunkowości z 2014 r. i nowych wzorów wynikających z nowelizacji ustawy o rachunkowości z 2016 r. zestawiono w tabeli 1.

Ujednolicenie obowiązków sprawozdawczych wiąże się też z narzuceniem jednolitej wersji sprawozdań zarówno organizacjom prowadzącym, jak i nieprowadzącym działalności gospodarczej. Dotychczas organizacje decydujące się na rozpoczęcie działalności gospodarczej sporządzały sprawozdania według wzorów określonych dla podmiotów gospodarczych. W zależności od spełniania ustawowych kryteriów dotyczących sumy bilansowej, wysokości osiąganych przychodów i zatrudnienia jednostki te mogły sporządzać sprawozdania w wersji dla jednostek mikro (załącznik nr 4 do ustawy o rachunkowości), w wersji dla jednostek małych (załącznik nr 5) lub w wersji pełnej (załącznik nr 1). Pojawiał się więc problem związany nie tylko z doborem wersji sprawozdania, ale też z koniecznością jej modyfikacji przez wynikający z ustawy o działalności pożytku publicznego i o wolontariacie (Ustawa z dnia 24 kwietnia 2003 r...., art. 10) obowiązek wyodrębnienia dodatkowych pozycji sprawozdawczych pozwalających na ujawnienie przychodów i kosztów działalności nieodpłatnej i odpłatnej pożytku publicznego.

Organizacje mają możliwość prowadzenia działalności pożytku publicznego jako działalności nieodpłatnej lub odpłatnej, za którą pobierają wynagrodzenie. Posiadanie statusu OPP nie jest warunkiem prowadzenia odpłatnej działalności pożytku publicznego. Zapisy ustawy o działalności pożytku publicznego i o wolontariacie (art. 6-10) odnoszą się do wszystkich organizacji, które działają w sferze pożytku, a nie tylko do organizacji, które mają przyznany status OPP.

Istnieje również możliwość rejestracji działalności gospodarczej, z której zyski przeznaczane są na finansowanie działań społecznie użytecznych. Rozpoczęcie działalności gospodarczej wiąże się jednak z utratą możliwości korzystania z uproszczeń w prowadzeniu rachunkowości, takich jak odstąpienie od przestrzegania zasady ostrożności. Organizacje nie mogą prowadzić działalności gospodarczej i odpłatnej działalności pożytku publicznego w odniesieniu do tego samego przedmiotu działalności. 
Tabela 1. Porównanie zakresu informacyjnego wzorów rachunku zysków i strat dla organizacji nieprowadzących działalności gospodarczej

\begin{tabular}{|c|c|c|}
\hline $\begin{array}{l}\text { Rozporządzenie Ministra } \\
\text { Finansów z dnia } 15 \text { listopada } \\
2001 \mathrm{r} \text {. }\end{array}$ & $\begin{array}{c}\text { Ustawa z dnia } 11 \text { lipca } 2014 \mathrm{r} \text {. } \\
\text { o zmianie ustawy o rachunko- } \\
\text { wości }\end{array}$ & $\begin{array}{l}\text { Ustawa z dnia } 15 \text { grudnia } \\
2016 \text { r. o zmianie ustawy } \\
\text { o rachunkowości }\end{array}$ \\
\hline $\begin{array}{l}\text { Okres obowiązywania: } \\
\text { 2001-2013 }\end{array}$ & $\begin{array}{l}\text { Okres obowiązywania: } \\
\text { 2014-2016 }\end{array}$ & $\begin{array}{l}\text { Okres obowiązywania: } \\
\text { od } 2017 \text { r. }\end{array}$ \\
\hline $\begin{array}{l}\text { A. Przychody z działalności } \\
\text { statutowej }\end{array}$ & $\begin{array}{l}\text { A. Przychody z podstawo- } \\
\text { wej działalności operacyjnej } \\
\text { i zrównane z nimi, w tym: }\end{array}$ & $\begin{array}{l}\text { A. Przychody z działalności } \\
\text { statutowej }\end{array}$ \\
\hline $\begin{array}{l}\text { I. Składki brutto określone } \\
\text { statutem }\end{array}$ & I. Zmiana stanu produktów & $\begin{array}{l}\text { I. Przychody z nieodpłatnej } \\
\text { działalności pożytku publicz- } \\
\text { nego }\end{array}$ \\
\hline $\begin{array}{l}\text { II. Inne przychody określone } \\
\text { statutem }\end{array}$ & - & $\begin{array}{l}\text { II. Przychody z odpłatnej dzia- } \\
\text { łalności pożytku publicznego }\end{array}$ \\
\hline- & - & $\begin{array}{l}\text { III. Przychody z pozostałej } \\
\text { działalności statutowej }\end{array}$ \\
\hline $\begin{array}{l}\text { B. Koszty realizacji zadań } \\
\text { statutowych }\end{array}$ & $\begin{array}{l}\text { B. Koszty podstawowej dzia- } \\
\text { falności operacyjnej: }\end{array}$ & $\begin{array}{l}\text { B. Koszty działalności statu- } \\
\text { towej }\end{array}$ \\
\hline- & I. Amortyzacja & $\begin{array}{l}\text { I. Koszty nieodpłatnej działal- } \\
\text { ności pożytku publicznego }\end{array}$ \\
\hline- & $\begin{array}{l}\text { II. Zużycie materiałów } \\
\text { i energii }\end{array}$ & $\begin{array}{l}\text { II. Koszty odpłatnej działalno- } \\
\text { ści pożytku publicznego }\end{array}$ \\
\hline- & $\begin{array}{l}\text { III. Wynagrodzenia, ubez- } \\
\text { pieczenia społeczne i inne } \\
\text { świadczenia }\end{array}$ & $\begin{array}{l}\text { III. Koszty pozostałej działal- } \\
\text { ności statutowej }\end{array}$ \\
\hline- & IV. Pozostałe koszty & - \\
\hline $\begin{array}{l}\text { C. Wynik finansowy na dzia- } \\
\text { łalności statutowej }(\mathrm{A}-\mathrm{B})\end{array}$ & - & $\begin{array}{l}\text { C. Zysk (strata) z działalności } \\
\text { statutowej }(\mathrm{A}-\mathrm{B})\end{array}$ \\
\hline- & - & $\begin{array}{l}\text { D. Przychody z działalności } \\
\text { gospodarczej }\end{array}$ \\
\hline- & - & $\begin{array}{l}\text { E. Koszty działalności gospo- } \\
\text { darczej }\end{array}$ \\
\hline- & - & $\begin{array}{l}\text { F. Zysk (strata) z działalności } \\
\text { gospodarczej (D - E) }\end{array}$ \\
\hline D. Koszty administracyjne & - & G. Koszty ogólnego zarządu \\
\hline 1. Zużycie materiałów i energii & - & - \\
\hline 2. Usługi obce & - & - \\
\hline 3. Podatki i opłaty & - & - \\
\hline $\begin{array}{l}\text { 4. Wynagrodzenia oraz } \\
\text { ubezpieczenia społeczne i inne } \\
\text { świadczenia }\end{array}$ & - & - \\
\hline
\end{tabular}


cd. tabeli 1

\begin{tabular}{|c|c|c|}
\hline $\begin{array}{l}\text { Rozporządzenie Ministra } \\
\text { Finansów z dnia } 15 \text { listopada } \\
2001 \mathrm{r} \text {. }\end{array}$ & $\begin{array}{c}\text { Ustawa z dnia } 11 \text { lipca } 2014 \mathrm{r} \text {. } \\
\text { o zmianie ustawy o rachunko- } \\
\text { wości }\end{array}$ & $\begin{array}{l}\text { Ustawa z dnia } 15 \text { grudnia } \\
2016 \text { r. o zmianie ustawy } \\
\text { o rachunkowości }\end{array}$ \\
\hline 5. Amortyzacja & - & - \\
\hline 6. Pozostałe & - & - \\
\hline- & - & $\begin{array}{l}\text { H. Zysk (strata) z działalności } \\
\text { operacyjnej }(\mathrm{C}+\mathrm{F}-\mathrm{G})\end{array}$ \\
\hline $\begin{array}{l}\text { E. Pozostałe przychody } \\
\text { (niewymienione w pozycjach } \\
\text { A i G) }\end{array}$ & C. Pozostałe przychody i zyski & $\begin{array}{l}\text { I. Pozostałe przychody opera- } \\
\text { cyjne }\end{array}$ \\
\hline $\begin{array}{l}\text { F. Pozostałe koszty (niewymie- } \\
\text { nione w pozycjach B, D i H) }\end{array}$ & D. Pozostałe koszty i straty & J. Pozostałe koszty operacyjne \\
\hline G. Przychody finansowe & - & K. Przychody finansowe \\
\hline H. Koszty finansowe & - & L. Koszty finansowe \\
\hline $\begin{array}{l}\text { I. Wynik finansowy brutto na } \\
\text { całokształcie działalności } \\
(\mathrm{C}-\mathrm{D}+\mathrm{E}-\mathrm{F}+\mathrm{G}-\mathrm{H})\end{array}$ & - & - \\
\hline J. Zyski i straty nadzwyczajne & - & - \\
\hline I. Zyski nadzwyczajne & - & - \\
\hline II. Straty nadzwyczajne & - & - \\
\hline- & - & $\begin{array}{l}\text { M. Zysk (strata) brutto } \\
(\mathrm{H}+\mathrm{I}-\mathrm{J}+\mathrm{K}-\mathrm{L})\end{array}$ \\
\hline- & E. Podatek dochodowy & N. Podatek dochodowy \\
\hline $\begin{array}{l}\text { K. Wynik finansowy ogółem } \\
(\mathrm{I}+\mathrm{J}) \text {, w tym: }\end{array}$ & $\begin{array}{l}\text { F. Wynik finansowy netto } \\
\text { ogółem }(A-B+C-D-E) \text {, } \\
\text { w tym: }\end{array}$ & O. Zysk (strata) netto $(\mathrm{M}-\mathrm{N})$ \\
\hline $\begin{array}{l}\text { I. Różnica zwiększająca koszty } \\
\text { roku następnego }\end{array}$ & $\begin{array}{l}\text { I. Nadwyżka przychodów nad } \\
\text { kosztami }\end{array}$ & - \\
\hline $\begin{array}{l}\text { II. Różnica zwiększająca przy- } \\
\text { chody roku następnego }\end{array}$ & $\begin{array}{l}\text { II. Nadwyżka kosztów nad } \\
\text { przychodami }\end{array}$ & - \\
\hline
\end{tabular}

Źródło: opracowanie własne na podstawie (Rozporządzenie Ministra Finansów z dnia 15 listopada 2001 r. ..., Ustawa z dnia 11 lipca 2014 r. ..., Ustawa z dnia 15 grudnia 2016 r....).

Jednocześnie ustawodawca wprowadził obowiązek rachunkowego wyodrębnienia kosztów, przychodów i wyników dotyczących poszczególnych rodzajów działalności, co z założenia ma przyczyniać się do prawidłowości rozliczeń, umożliwiając jednoznaczne przyporządkowanie poszczególnych operacji gospodarczych do działalności nieodpłatnej, odpłatnej i gospodarczej. Konieczność wyodrębnienia w rachunku zysków i strat przychodów i kosztów poszczególnych rodzajów działalności prowadziła do modyfikacji wzorów sprawozdań. W przy- 
padku badanych organizacji obowiązek ten był realizowany poprzez dodanie w rachunku zysków i strat:

- we wzorze wynikającym z rozporządzenia Ministra Finansów z dnia 15 listopada 2001 r. odpowiednich pozycji szczegółowych do przychodów z działalności statutowej i kosztów realizacji zadań statutowych,

- we wzorze wynikającym z ustawy z dnia 11 lipca 2014 r. o zmianie ustawy o rachunkowości pozycji uszczegóławiających przychody i koszty działalności podstawowej wobec nieuwzględnienia osobnych sekcji sprawozdania dla przychodów i kosztów działalności statutowej.

Badane organizacje posiadające status OPP oraz publikujące sprawozdania w bazie ministerialnej we wszystkich przypadkach spełniały obowiązek wyodrębniania przychodów i kosztów poszczególnych rodzajów działalności. Część jednostek prowadzących działalność pożytku publicznego i niepublikujących sprawozdań w bazie ministerialnej odstępowało od realizacji tego obowiązku, co przedstawiono na rys. 3 .

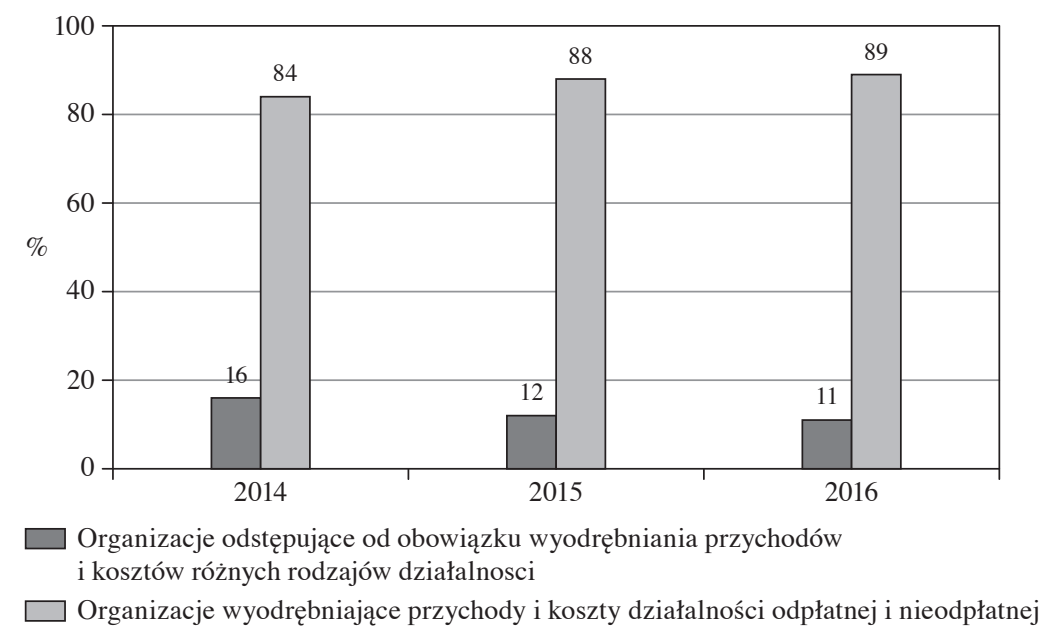

Rys. 3. Struktura organizacji ze względu na wyodrębnianie przychodów i kosztów działalności nieodpłatnej i odpłatnej w latach 2014-2016

Źródło: opracowanie własne.

Brak odpowiedniego uszczegółowienia informacji mimo jednoczesnego prowadzenia działalności nieodpłatnej i odpłatnej można tłumaczyć narzuceniem organizacjom wzoru sprawozdania bardziej dostosowanego do potrzeb przedsiębiorstw. Wszystkie przychody i koszty działalności pożytku publicznego były więc 
wykazywane jako przychody i koszty działalności podstawowej, bez dokonywania modyfikacji wzoru sprawozdania. Można więc przypuszczać, że wprowadzenie nowego rachunku zysków i strat, obowiązującego od roku sprawozdawczego 2017, wyeliminuje ten problem i przyczyni się do pełnej polityki informacyjnej, pozwalającej na ustalenie wyników z poszczególnych rodzajów prowadzonej przez organizacje działalności.

Jak wcześniej wspomniano, istotnym mankamentem nowej wersji sprawozdania jest niekonsekwencja w stosowaniu określeń „nadwyżka przychodów” i „nadwyżka kosztów” w odniesieniu do wyniku finansowego organizacji non-profit. Taka nomenklatura od dawna stosowana jest w literaturze przedmiotu (por. Czubakowska i Winiarska 2010, s. 164; Nawrocki 2017, s. 169) oraz w praktyce rachunkowości organizacji pożytku publicznego.

W sprawozdaniach finansowych badanej grupy jednostek za lata 2014-2016, sporządzanych na wzorach wynikających z nowelizacji ustawy o rachunkowości z 2014 r. można odnaleźć przykłady stosowania pojęć zysku lub straty mimo braku prowadzenia działalności gospodarczej. Dane dla badanej próby przedstawiono na rys. 4. Prezentowane wyniki dotyczą wyłącznie organizacji niepublikujących sprawozdań w bazie ministerialnej, gdyż w przypadku publikacji odpowiednie opisy pozycji sprawozdawczych były automatycznie narzucane.

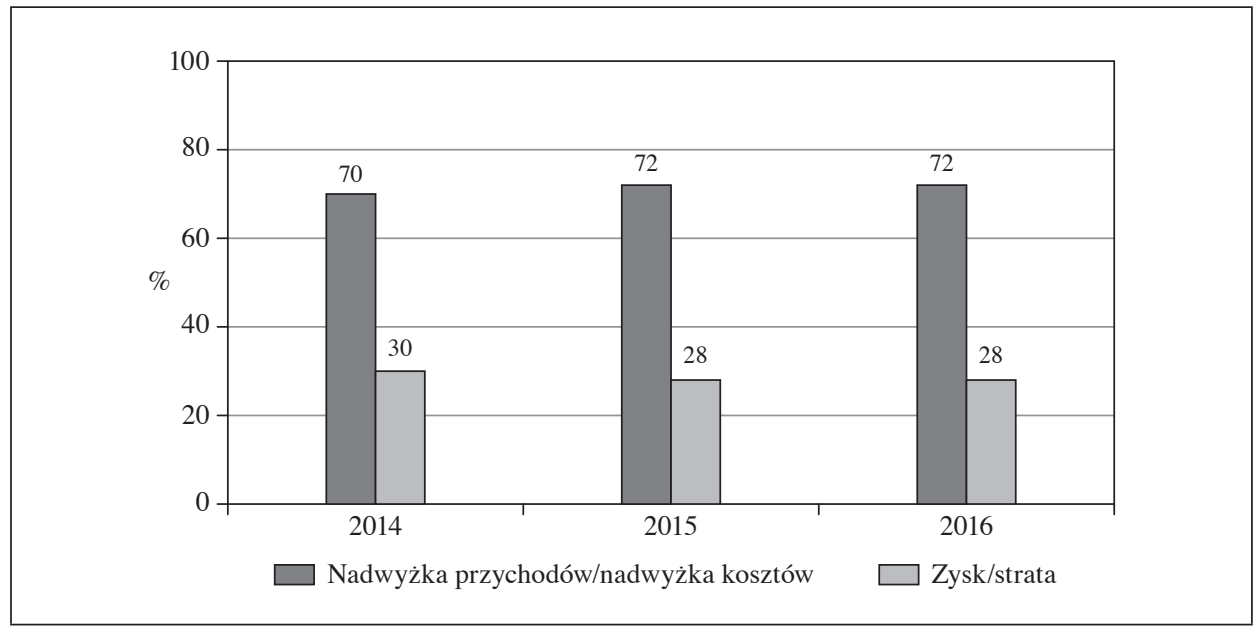

Rys. 4. Struktura organizacji ze względu na sposób określania wyniku finansowego w latach 2014-2016

Źródło: opracowanie własne.

Problem stosowania odpowiedniego nazewnictwa wynikał z przyjęcia dla organizacji non-profit wzorów sprawozdań dla jednostek mikro, wynikających 
z załącznika nr 4 do ustawy o rachunkowości. Załącznik określał wprawdzie wariantowo dwa możliwe rozwiązania sprawozdawcze, wśród których znalazło się podejście wyodrębniające nadwyżkę przychodów lub nadwyżkę kosztów. Najwyraźniej jednak organizacje przyjęły zbyt dosłownie narzuconą konieczność sporządzania sprawozdań według wzorów dla przedsiębiorstw uznawanych za jednostki mikro.

Nowy wzór rachunku zysków i strat mający zastosowanie od roku sprawozdawczego 2017 całkowicie pomija specyfikę wyniku organizacji non-profit, ponieważ używa się w nim jedynie określeń ,zysk” i ,strata”. Wynika to zapewne z jednolitego charakteru sprawozdania, umożliwiającego wykorzystanie go zarówno przez organizacje prowadzące, jak i nieprowadzące działalności gospodarczej. Problematyczna pozostaje więc kwestia, czy nowe regulacje doprowadzą do całkowitego odejścia od dotychczasowego nazewnictwa, czy też organizacje nieprowadzące działalności gospodarczej będą dążyć do modyfikacji opisu pozycji sprawozdawczych.

\section{Podawanie sprawozdań finansowych i merytorycznych do publicznej wiadomości}

Na organizacje pożytku publicznego nałożony został także obowiązek przekazywania sporządzanych sprawozdań finansowych i merytorycznych do właściwych organów oraz ich upubliczniania w sposób umożliwiający zapoznanie się z ich treścią zainteresowanym osobom. Ustawa o działalności pożytku publicznego i o wolontariacie (art. 23), uwzględniająca zmiany obowiązujące od 2011 r., nakłada na organizacje posiadające status OPP obowiązek przekazania sprawozdań finansowych i merytorycznych ministrowi właściwemu do spraw zabezpieczenia społecznego w terminie 15 dni od dnia zatwierdzenia sprawozdania finansowego oraz podanie sprawozdań do publicznej wiadomości w sposób umożliwiający zapoznanie się z tymi sprawozdaniami przez zainteresowane podmioty, w tym poprzez zamieszczenie na stronach internetowych organizacji. Sprawozdania należy także zamieścić na stronie internetowej urzędu obsługującego ministra właściwego do spraw zabezpieczenia społecznego w terminie 15 dni od dnia zatwierdzenia rocznego sprawozdania finansowego.

Obecnie nie obowiązuje wymóg przesyłania pocztą papierowej wersji sprawozdań, ograniczono też obowiązki organizacji wyłącznie do publikacji sprawozdania finansowego i merytorycznego na stronie internetowej ministerstwa. Sprawozdania elektroniczne powinny być publikowane w bazie ministerialnej do 15 lipca roku następującego po roku, za który składane jest sprawozdanie finansowe i merytoryczne. Organizacje, których rok obrotowy nie pokrywa się 
$\mathrm{z}$ rokiem kalendarzowym, zobowiązane są do przekazania sprawozdań w terminie 15 dni od dnia ich zatwierdzenia.

Sprawozdanie finansowe organizacji pożytku publicznego powinno zostać zatwierdzone przez odpowiednie władze i przyjęte najpóźniej do końca szóstego miesiąca od dnia zakończenia roku obrotowego. W zależności od formy prawnej działalności organizacji sprawozdanie może być zatwierdzane m.in. przez radę fundacji lub walne zebranie. Organ zatwierdzający sprawozdanie powinien być określony w statucie organizacji.

Na praktyczną realizację obowiązków związanych z upublicznianiem sprawozdań finansowych największy wpływ miało wprowadzenie sankcji dla organizacji niewywiązujących się z tych obowiązków w ustawowym terminie. Jest nią nieuwzględnienie jednostki w spisie organizacji uprawnionych do otrzymywania środków z $1 \%$ podatku dochodowego od osób fizycznych. W przypadku, gdy złożone sprawozdanie budzi wątpliwości lub jest niepełne, minister właściwy do spraw zabezpieczenia społecznego wzywa organizację do zaniechania naruszeń i przedstawienia wyjaśnień. Niezastosowanie się do wezwania w ciągu 30 dni od daty jego otrzymania grozi odebraniem statusu organizacji pożytku publicznego w Krajowym Rejestrze Sądowym.

Wobec powyższego realizacja obowiązków informacyjnych związanych z podawaniem sprawozdań finansowych i merytorycznych do publicznej wiadomości uległa znaczącemu polepszeniu. Jeszcze w 2010 r. 3\% organizacji posiadających status organizacji pożytku publicznego przekazało sprawozdania po ustawowym terminie, a 46\% nie przekazało ich w ogóle (Zieniuk 2012, s. 193). Obecnie problem ten został praktycznie wyeliminowany. W badanej próbie 100 organizacji posiadających status OPP wszystkie opublikowały swoje sprawozdania finansowe i merytoryczne w ustawowym terminie.

\section{Sprawozdanie merytoryczne jako uszczegółowienie sprawozdania finansowego organizacji pożytku publicznego}

Oprócz sprawozdania finansowego organizacje posiadające status OPP sporządzają zgodnie z ustawą o działalności pożytku publicznego i o wolontariacie (art. 23, ust. 1) sprawozdanie merytoryczne z działalności pożytku publicznego, które zwiększa zakres ujawnianych informacji dla zapewnienia przejrzystości funkcjonowania organizacji i prowadzonej przez nie gospodarki finansowej. Wprowadzenie wzoru sprawozdania merytorycznego wynikającego z rozporządzenia Ministra Pracy i Polityki Społecznej z dnia 23 marca 2011 r. zdecydowanie zwiększyło zakres ujawnianych przez organizacje informacji, w tym przekrój prezentacyjny przychodów i kosztów. Obecnie obowiązujące rozporządzenie 
Ministra Pracy i Polityki Społecznej z dnia 12 lutego 2013 r. dopuszcza także możliwość sporządzania uproszczonego sprawozdania merytorycznego dla organizacji o niskim rocznym przychodzie, nieprzekraczającym 100000 zł.

Dane prezentowane w sprawozdaniu finansowym organizacji pożytku publicznego mogą nie być wyczerpujące dla zaspokojenia potrzeb informacyjnych odbiorców. Wynika to ze specyfiki prowadzenia działań społecznie użytecznych i związanej z nią konieczności finansowania działalności organizacji z wielu różnych źródeł, takich jak darowizny, zbiórki publiczne, dotacje, granty, sponsoring, składki członkowskie, spadki i zapisy, mechanizm $1 \%$ podatku dochodowego, działalność odpłatna i gospodarcza. Społeczne cele prowadzonej działalności i chęć dalszego pozyskiwania środków wymuszają na organizacjach dodatkowe, bardziej szczegółowe ujawnienia informacyjne, pozwalające na rozliczenie się z otoczeniem z rezultatów swojej działalności. Praktyczną realizacją tej potrzeby jest wymóg sporządzania sprawozdania merytorycznego.

Organizacje sporządzające sprawozdanie merytoryczne zobowiązane są do podania informacji o osiąganych przychodach w podziale na:

- przychody z działalności nieodpłatnej pożytku publicznego,

- przychody z działalności odpłatnej pożytku publicznego,

- przychody z działalności gospodarczej,

- przychody finansowe,

- pozostałe przychody.

Dodatkowo organizacje publikują dane pozwalające na identyfikację źródeł ich przychodów. Zakres ujawnianych informacji jest w tym przypadku dużo szerszy niż w rachunku zysków i strat, sporządzanym zarówno według dotychczasowych, jak i nowych wzorów. W sprawozdaniu merytorycznym podawane są do wiadomości następujące przychody:

1) z $1 \%$ podatku dochodowego od osób fizycznych;

2) ze źródeł publicznych ogółem, w tym:

- ze środków europejskich w rozumieniu przepisów o finansach publicznych,

- ze środków budżetu państwa,

- ze środków budżetu jednostek samorządu terytorialnego,

- ze środków państwowych funduszy celowych;

3) ze źródeł prywatnych ogółem, w tym:

- ze składek członkowskich,

$-\mathrm{z}$ darowizn od osób fizycznych,

- z darowizn od osób prawnych,

- z ofiarności publicznej (zbiórek publicznych, kwest),

- ze spadków, zapisów,

- z wpływów z majątku (w szczególności sprzedaży lub wynajmu składników majątkowych); 
4) z innych źródeł.

Informacje o kosztach poniesionych przez organizacje w roku sprawozdawczym ujawniane są $\mathrm{w}$ podziale na:

- koszty z tytułu prowadzenia nieodpłatnej działalności pożytku publicznego,

- koszty z tytułu prowadzenia odpłatnej działalności pożytku publicznego,

- koszty z tytułu prowadzenia działalności gospodarczej,

- koszty finansowe,

- koszty administracyjne,

- pozostałe koszty ogółem.

Do każdej z wymienionych pozycji należy dodatkowo podać wysokość kosztów finansowanych z $1 \%$ podatku dochodowego od osób fizycznych, a także ujawnić wysokość kosztów kampanii informacyjnej lub reklamowej związanej z pozyskiwaniem środków z mechanizmu $1 \%$ podatku dochodowego. Dane o przychodach i kosztach w uproszczonym sprawozdaniu merytorycznym są prezentowane w podobnym przekroju, ale z mniejszą szczegółowością. Przychody ze źródeł publicznych i prywatnych podaje się w kwocie ogółem, bez wyróżniania dokładnych informacji o ich pochodzeniu.

Niezależnie od tego, czy organizacje sporządzają sprawozdanie merytoryczne w pełnej, czy uproszczonej formie, informacje o przychodach i kosztach prezentowane są w dużo szerszym zakresie niż w rachunku zysków i strat, sporządzanym zarówno według dotychczasowych, jak i nowych wzorów. Należy więc zgodzić się ze stanowiskiem, że przydatność sprawozdań finansowych byłaby większa, gdyby część informacji liczbowych ze sprawozdania merytorycznego była prezentowana w rachunku zysków i strat, co pozwoliłoby wzbogacić jego treść, a zarazem uniknąć powtórzeń (Waniak-Michalak 2015).

Konieczność prezentowania informacji o przychodach i kosztach w określonych przekrojach wymaga od organizacji dostosowania ewidencji księgowej. Niezbędne jest więc tworzenie nowych kont syntetycznych lub rozbudowanie systemu kont analitycznych, pozwalające na wyodrębnienie wpływów środków otrzymywanych z różnych tytułów i kierunków ich wykorzystania. Wiąże się to również z dokładnym określaniem, z jakich źródeł pochodzą środki wydatkowane na określone cele, co w praktyce sprawia organizacjom liczne problemy i powoduje częste występowanie korekt księgowego ujęcia dokonywanych wydatków.

\section{Podsumowanie}

Na podstawie przeprowadzonych rozważań i zaprezentowanych wyników badań empirycznych można stwierdzić, że organizacje pożytku publicznego natrafiają na wiele praktycznych problemów w realizacji obowiązków sprawozdaw- 
czych. Wynika to m.in. z ciągłych zmian regulacji prawnych oraz z dużej kosztochłonności profesjonalnej obsługi księgowej, na którą nie wszystkie jednostki mogą sobie pozwolić.

Wprowadzenie sankcji za brak publikacji sprawozdań finansowych i merytorycznych w ustawowym terminie praktycznie wyeliminowało problem uchylania się jednostek mających status OPP od wypełniania obowiązków sprawozdawczych. Konstrukcja bazy sprawozdań wyklucza też wiele technicznych nieścisłości związanych z ujawnianymi informacjami. Organizacje prowadzące działalność pożytku publicznego, niezobligowane do publikacji sprawozdań w bazie ministerialnej nadal jednak mają pewne problemy związane m.in. z doborem właściwej wersji sprawozdań finansowych i wyodrębnianiem informacji o poszczególnych rodzajach działalności.

Ujednolicenie obowiązków sprawozdawczych od roku sprawozdawczego 2017 w przypadku ich konsekwentnej realizacji przez organizacje może w opinii autora przyczynić się do rozwiązania problemów związanych z właściwym doborem wzorów sprawozdań i koniecznością ich modyfikacji, a także stworzy możliwość łatwiejszego porównywania sprawozdań organizacji prowadzących i nieprowadzących działalności gospodarczej.

\section{Literatura}

Czubakowska K., Winiarska K. (2010), Rachunkowość fundacji, stowarzyszeń i innych jednostek nieprowadzq̨cych działalności gospodarczej, PWE, Warszawa.

Nawrocki R. (2017), Rachunkowość fundacji i stowarzyszeń, Ośrodek Doradztwa i Doskonalenia Kadr, Gdańsk.

Odpowiedź Ogólnopolskiej Federacji Organizacji Pozarzqdowych dotyczqca projektu ustawy o zmianie ustawy o rachunkowości w zakresie, $w$ którym reguluje prowadzenie ksiegowości przez organizacje pozarzqdowe (2014), http://legislacja.rcl.gov.pl/ docs//2/171214/171217/171220/dokument84145.pdf (data dostępu: 16.08.2017).

Podstawowe fakty o organizacjach pozarzqdowych (2013), Stowarzyszenie Klon/Jawor, Warszawa.

Rozporząazenie Ministra Finansów z dnia 15 listopada 2001 r. w sprawie szczególnych zasad rachunkowości dla niektórych jednostek niebędących spółkami handlowymi, nieprowadzących działalności gospodarczej, Dz.U. nr 137, poz. 1539.

Rozporządzenie Ministra Pracy i Polityki Społecznej z dnia 23 marca 2011 r. w sprawie rocznego sprawozdania merytorycznego z działalności organizacji pożytku publicznego, Dz.U. nr 80, poz. 434.

Rozporządzenie Ministra Pracy i Polityki Społecznej z dnia 12 lutego 2013 r. w sprawie wzorów rocznego sprawozdania merytorycznego oraz rocznego uproszczonego sprawozdania merytorycznego z działalności organizacji pożytku publicznego, Dz.U. poz. 234.

Ustawa z dnia 24 kwietnia 2003 r. o działalności pożytku publicznego i o wolontariacie, Dz.U. 2016, poz. 1817. 
Ustawa z dnia 11 lipca 2014 r. o zmianie ustawy o rachunkowości, Dz.U. poz. 1100.

Ustawa z dnia 15 grudnia 2016 r. o zmianie ustawy o rachunkowości, Dz.U. 2017, poz. 61. Waniak-Michalak H. (2015), Nowe wymogi dotyczq̨e rachunkowości stowarzyszén i fundacji, ,Rachunkowość”, nr 6.

Zieniuk P. (2012), Obowiązki sprawozdawcze organizacji pożytku publicznego - kierunki zmian (w:) Kierunki ewolucji sprawozdawczości i rewizji finansowej, red. B. Micherda, Difin, Warszawa.

\section{The Practical Aspects of Unifying the Reporting Requirements of Public Benefit Organisations}

(Abstract)

The amendment to the accounting law of 15 December 2016 implemented new, unified formats of financial statements for public benefit organisations. Those formats will be applied in reports prepared after the 1st of January 2017. The article presents practical aspects of the new regulations' implementation in a synthetical manner. From the author's viewpoint, the new report format matches more the character of activities carried out in the third sector. At the same time, it eliminates problems connected with the need to adjust the format of past reports to the requirements of disclosing revenues and costs of unchargeable, chargeable and economic activities. The results of research carried out on organisations operating in Małopolska are also presented. The research shows the scale of the problem of correctly choosing the format for financial reporting.

Keywords: public benefit organisations, foundations, associations, financial statements unification. 